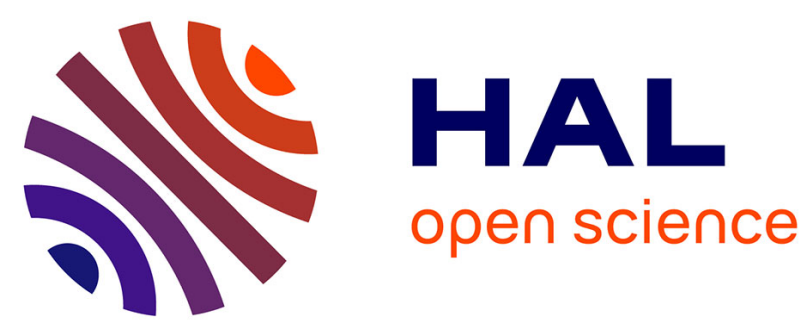

\title{
Caesarean section at term: the relationship between neonatal respiratory morbidity and microviscosity in amniotic fluid.
}

Vincent Lavoué, Laure Voguet, Bruno Laviolle, Caroline Piau, Marie Pascale Beaumont, Laure-Anne Haumont, Hélène Isly, Linda Lassel, Estelle Bauville, Karine Morcel, et al.

\section{To cite this version:}

Vincent Lavoué, Laure Voguet, Bruno Laviolle, Caroline Piau, Marie Pascale Beaumont, et al.. Caesarean section at term: the relationship between neonatal respiratory morbidity and microviscosity in amniotic fluid.. European Journal of Obstetrics \& Gynecology and Reproductive Biology, 2013, 169 (2), pp.239-43. 10.1016/j.ejogrb.2013.05.003 . hal-00860266

\section{HAL Id: hal-00860266 \\ https://hal-univ-rennes1.archives-ouvertes.fr/hal-00860266}

Submitted on 10 Sep 2013

HAL is a multi-disciplinary open access archive for the deposit and dissemination of scientific research documents, whether they are published or not. The documents may come from teaching and research institutions in France or abroad, or from public or private research centers.
L'archive ouverte pluridisciplinaire HAL, est destinée au dépôt et à la diffusion de documents scientifiques de niveau recherche, publiés ou non, émanant des établissements d'enseignement et de recherche français ou étrangers, des laboratoires publics ou privés. 
Caesarean section at term: the relationship between neonatal respiratory morbidity and microviscosity in amniotic fluid

Vincent LAVOUÉ ${ }^{1,4 *}$, MD., PhD, Laure VOGUET ${ }^{1 *}$, MD., Bruno LAVIOLLE $^{5}$, MD., PhD., Caroline PIAU ${ }^{3}$, PharmD., Marie Pascale BEAUMONT ${ }^{3}$, PharmD., Laure-Anne HAUMONT $^{4}$, Hélène ISLY ${ }^{1}$, MD., Linda LASSEL ${ }^{1}$, MD., Estelle BAUVILLE ${ }^{1}$, MD., Karine MORCEL ${ }^{1}$, MD., PhD, Patrick PLADYS ${ }^{2}$, MD., PhD, Patrice POULAIN ${ }^{1}$, MD, Pierre BÉTRÉMIEUX², MD., Claude BENDAVID, MD., $\mathrm{PhD}^{3,4}$

1: Department of Obstetrics, Rennes University Hospital, Rennes, France

2: Department of Paediatric, Rennes University Hospital, Rennes, France

3: Department of Biochemistry, Rennes University Hospital, Rennes, France, and

4: Institute of Health and Medical Research (INSERM) U991, University of Rennes 1, Rennes, France

5: Department of Clinical Pharmacology and INSERM Clinical Investigation Centre (CIC) 0203, University Hospital, University of Rennes 1, Rennes, France

Corresponding author: Dr Claude Bendavid, claude.bendavid@chu-rennes.fr, Department of Biochemistry, Rennes University Hospital, Rennes, France. Tel: 33(0) 299285977. Fax: 33(0) 299266723.

Disclosure: none of the authors report any conflicts of interest.

*Both authors contributed equally to this work 


\section{CONDENSATION}

Our study shows that surfactant maturity, as quantified by the microviscosity of amniotic fluid taken at delivery, continues to increase past term age and that it correlates with postnatal respiratory morbidity.

Running title: neonatal respiratory morbidity and amniotic fluid 


\section{ABSTRACT}

Objectives: The incidence of neonate respiratory morbidity following an elective caesarean section is 2 or 3 times higher than after a vaginal delivery. The microviscosity of surfactant phospholipids, as measured with fluorescence polarisation, is linked with the functional characteristics of foetal surfactant and thus foetal lung maturity. To date, this point has received little attention in new-borns at term. The aim of the study is to evaluate the correlation between neonatal respiratory morbidity and amniotic microviscosity (Fluorescence Polarisation Index) in women undergoing caesarean section after 37 weeks' gestation.

Study design: The files of 136 women who had undergone amniotic microviscosity studies during elective caesarean deliveries at term were anonymised. Amniotic fluid immaturity (AFI) was defined as a Fluorescence Polarisation Index higher than 0.335.

Results: Respiratory morbidity was observed in 10 babies (7.3\%) and was independently associated with AFI (OR: 6.11 [95\% CI, 1.20-31.1] with $p=0.029)$ and body mass index (OR: 1.12 [95\% CI, 1.02-1.22] with $p=0.019)$. Gestational age at the time of caesarean delivery was inversely associated with AFI (odds ratio, 0.46 [95\% confidence interval, 0.29-0.71], $\mathrm{p}<0.001$ ), especially before 39 weeks, and female gender was associated with an increased risk (odds ratio, 3.29 [95\% confidence interval, 1.48-7.31], $\mathrm{p}=0.004$ ).

Conclusions: AFI assessed by amniotic microviscosity was significantly associated with respiratory morbidity and independently correlated with shorter gestational age especially before 39 weeks. This finding provides a physiological rationale for recommending delaying elective caesarean section delivery until 39 weeks of gestation to decrease the risk for respiratory morbidity.

Keywords:

- Caesarean section 
- Respiratory Morbidity

- Surfactant

- Microviscosity

- Fluorescence Polarisation 


\section{Introduction:}

The number of caesarean section deliveries is increasing in both developed and developing countries [1]. The rate of caesareans is now 20\% in France [2] and 30\% in the United States [3]. The perceived risk for the neonate is small [4], but the incidence of respiratory morbidity following an elective caesarean section is 2 or 3 times higher than after a vaginal delivery [1, $3,5,6]$. Indeed, elective caesarean anticipates the date of spontaneous delivery and likely reduces the beneficial effect that labour has on lung adaptation $[7,8]$.

The mechanisms that allow for rapid clearing of the foetal lung air spaces of the amniotic fluid remain partially unclear [9]. "Starling forces" and "vaginal squeeze" are certainly involved. Activation of epithelial sodium channels in alveolar type II cells has emerged as a key event for fluid absorption and effective neonatal air breathing [10]. The onset of spontaneous labour is coupled with changes in the foetal hormonal environment that affect the epithelial sodium channels functions [11]. Another interesting parameter is the physical quality of the lung surfactant that is assessed by the microviscosity of the phospholipids in new-borns. The surfactant phospholipids microviscosity of amniotic fluid that is measured with fluorescence polarisation is linked with optimal or functional foetal pulmonary surfactant production and foetal lung maturity [12-14]. To date, this last point has received little attention in new-borns at term.

We studied the microviscosity of phospholipids in amniotic fluid with fluorescence polarisation [13, 15]. Microviscosity was measured in a population of women undergoing caesarean section after 37 weeks' gestation. The first aim of this study was to evaluate the correlation between the fluorescence polarisation in amniotic fluid and neonatal respiratory morbidity. The second aim was to evaluate the evolution of fluorescence polarisation between 37 and 41 weeks of gestation. 


\section{Materials and methods:}

\section{Patients}

We prospectively obtained a sample of the amniotic fluid during the caesarean surgery to measure the microviscosity of the phospholipids and we retrospectively reviewed the clinical files of women who had undergone caesarean sections at 37 weeks' gestation or beyond between 1 April, 2008 and 30 March, 2009. Patients who were undergoing planned elective caesareans and who experienced spontaneous labour or premature rupture of membranes before the caesarean section were included in the study. Women who were undergoing emergency caesarean sections without labour were also included. Informed consent was obtained from the study participants to sample their amniotic fluid for testing. The study protocol was approved by the local ethics committee.

The exclusion criteria were congenital malformations, twin pregnancies, failure of the amniotic fluid samples (too haematic for microviscosity measurements) and neonatal infection. Neonatal infection was defined as blood culture positive and/or peak C Reactive Protein $(\mathrm{CRP})>10 \mathrm{mg} / \mathrm{l}$ collected within the first 24 hours and/or at 48 hours of life.

\section{Data collection}

Gestational diabete was diagnosed using the 1999 World Health Organisation criteria: oral glucose tolerance test with a $75 \mathrm{~g}$ oral dose is performed between the $24^{\text {th }}$ and the $28^{\text {th }}$ week of pregnancy; the fasting plasma glucose measured before the oral glucose tolerance test begins should be below $6.1 \mathrm{mmol} / \mathrm{l}(110 \mathrm{mg} / \mathrm{dl})$, and the 2-hour oral glucose tolerance test glucose level should be below $7.8 \mathrm{mmol} / \mathrm{l}(140 \mathrm{mg} / \mathrm{dl})$. Labour was diagnosed as regular uterine contractions combined with cervical effacement and dilatation of $3 \mathrm{~cm}$ or more. Hypertension was defined as having a persistent systolic blood pressure greater than $140 \mathrm{mmHg}$ and/or persistent diastolic blood pressure greater than $90 \mathrm{mmHg}$. Intrauterine growth restriction (< $10^{\text {th }}$ centile) and macrosomia $\left(>90^{\text {th }}\right.$ centile) were defined with the AUDIPOG reference 
curves [16]. The diagnosis of neonatal respiratory morbidity was defined as any respiratory disease that required medical support (with more than $25 \%$ oxygen) for $>10 \mathrm{mn}$ to maintain neonate oxygen saturation $>90 \%$ [17]. The required medical supports were supplemental oxygen, nasal continuous positive airway pressure, endotracheal intubation, or exogenous surfactant. The neonates who were admitted with respiratory morbidity were given chest Xrays. The classic radiographic findings of transient tachypnea of the new-born or the reticulogranular pattern of respiratory distress syndrome were used to classify the chest Xrays [18]. The patient chest X-ray files were blindly reviewed by an expert (PB) for the radiological features of tachypnea of the new-born or respiratory distress syndrome.

\section{Method of obtaining the amniotic fluid sample}

During each caesarean section, shortly after the hysterotomy and before the neonate extraction, amniotic fluid was collected using a sterile plastic syringe. At night, the samples were stored overnight at $4^{\circ} \mathrm{C}$, and processed the next day in the laboratory. At working days, the samples were immediately processed in the laboratory.

\section{Measuring phospholipid microviscosity in amniotic fluid using fluorescence polarisation}

The amniotic fluid was centrifuged (15 mn, $3500 \mathrm{RPM})$ and the supernatant transferred to a secondary tube to avoid contaminating the surfactant with the phospholipids from the cells and the vernix. The surfactant phospholipids were labelled using 1,6-diphenyl-1,3,5hexatriene. Then, $1 \mathrm{ml}$ of amniotic supernatant was added to $3 \mathrm{ml}$ of working solution in a 5 $\mathrm{ml}$ tube. The mix was sonicated in a cup horn at an intensity of 10 watts for $1 \mathrm{mn}$ to reorganise the surfactant phospholipids in homogeneous liposomes and integrate the 1,6diphenyl-1,3,5-hexatriene probes. The mix was immediately transferred into a quartz cell to read the fluorescence on a PTI QuantaMaster (excitation wavelength $360 \mathrm{~nm}$, emission wavelength $460 \mathrm{~nm})$. The polarisation filters on the excitation $\left(E_{x}\right)$ and emission $\left(E_{m}\right)$ sides of 
the quartz cell were alternatively used in vertical $\left(\mathrm{E}_{\mathrm{xV}}\right.$ and $\left.\mathrm{E}_{\mathrm{mV}}\right)$ and horizontal $\left(\mathrm{E}_{\mathrm{xH}}\right.$ and $\left.\mathrm{E}_{\mathrm{mH}}\right)$ orientations to obtain four different measurements of fluorescence intensity: parallel vertical intensity $\left(\mathrm{I}_{\mathrm{vV}}\right)$, perpendicular vertical intensity $\left(\mathrm{I}_{\mathrm{vh}}\right)$, parallel horizontal intensity $\left(\mathrm{I}_{\mathrm{hh}}\right)$ and perpendicular horizontal intensity $\left(\mathrm{I}_{\mathrm{hv}}\right)$. The fluorescence data were recorded using the FeliX32 analysis (version 1.2) software.

The polarisation anisotropy $(\mathrm{P})$ was calculated based on the ratio: $\mathrm{P}=(\mathrm{Ivv}-\mathrm{gIvh}) /(\mathrm{Ivv}+\mathrm{gIvh})$ with $\mathrm{g}=\mathrm{Ihh} / \mathrm{Ihv}$ and $(\mathrm{g}<1) . \mathrm{P}$ value and surfactant are inversely related to one another: a high $\mathrm{P}$ value corresponded to immature lung surfactant and conversely. The discriminatory ability of the Fluorescence Polarisation Index for detecting neonatal respiratory morbidity was measured using the area under the receiver operating characteristic curve (data not shown). The sensitivity and specificity values were calculated using various cut-offs. The previous published cut-off value of 0.335 was one of the best values for sensitivity and specificity for detecting neonatal respiratory morbidity [15]. For this reason, we choose 0.335 for the biological cut-off for the amniotic fluid fluorescence polarisation. The amniotic fluid immaturity (AFI) was defined as a Fluorescence Polarisation Index higher than 0.335.

\section{Outcome measures}

The primary outcome was respiratory morbidity. The secondary outcome was AFI.

\section{Statistical analysis}

Statistical analysis was performed using SAS Software v.9.1 (SAS Institute, Cary, NC, USA). The data are presented as the medians (first quartile - third quartile) for continuous variables, and numbers with the corresponding percentages for the qualitative variables. Our statistical plan included using two distinct univariate analyses to assess the characteristics of the study population that was associated with respiratory morbidity and AFI. Continuous variables were compared using the Wilcoxon rank sum test, and the categorical variables were analysed with 
the chi-squared test or Fisher's exact test (as appropriate). Finally, a logistic regression model was used to identify the risk-factors that were independently associated with the occurrence of respiratory morbidity and AFI. The variables that were found to have a p value $<0.1$ in the univariate analysis were entered into the model. Gestational diabetes was also entered in the model, as there is an established relationship between respiratory distress syndrome and gestational diabetes [19]. Finally, the correlation between the term delivery and the fluorescence polarisation was assessed using Pearson's correlation coefficient. For all of the analyses, $\mathrm{p}<0.05$ was considered to be statistically significant. 


\section{Results:}

\section{Characteristic of the study population}

A total of 136 women were enrolled in the study. The overall rates of caesarean sections for deliveries and elective caesarean sections at our university hospital were $20.7 \%$ and $8.7 \%$, respectively. The mothers' clinical characteristics are summarised in table 1 . The median age of the mothers was 32 years (29-36), and their median body mass index at the beginning of the pregnancy was $22.7 \mathrm{Kg} / \mathrm{m}^{2}(20.3-27.1)$. The median gestational age at the time of the caesarean section was 39.0 weeks (38.4-39.2). The median birth weight was $3315 \mathrm{~g}$ (3020$3665)$. The sex ratio was 1.0 (68 boys and 68 girls). Intrauterine growth restriction $\left(<10^{\text {th }}\right.$ centile) was diagnosed in 10 neonates $(7.3 \%)$, and macrosomia $\left(>90^{\text {th }}\right.$ centile) was diagnosed in 26 neonates (19\%). Among the 26 gestations with macrosomia, 9 (53\%) had gestational diabetes.

\section{Study outcome}

A total of 10 neonates $(7.3 \%)$ showed respiratory morbidity at birth or in the first hours after birth, and required oxygen (table 2). There were 7 females and 3 males; the median birth weight was $3313 \mathrm{~g}$ (2905-3890), and the median gestational age was 38.6 weeks (37.9-39.0). Six neonates showed moderate respiratory morbidity, and four showed mild respiratory morbidity. None required tracheal intubation or mechanical ventilation. Six neonates were hospitalised in the nearby neonatal intensive care unit and four stayed in the maternity ward. The reason for hospitalisation was continuous positive airway pressure necessity. Six neonates were placed in an oxygen hood, and two received oxygen through nasal cannulas. Six women underwent caesarean sections because of past caesarean sections (third caesarean section in 3 cases), two for breech presentation, one for HIV, and one for diabetes mellitus. The Apgar scores were 9 to 10 for all of the neonates at $5 \mathrm{mn}$. The maximal fraction of 
inspired oxygen required was 0.45 . Chest X-rays were taken in 7 of 10 neonates. The X-rays showed interstitial bilateral opacities compatible with tachypnea of the new-born in five neonates and bronchogram in favour of mild respiratory distress syndrome in two others (those who had continuous positive airway pressure). All of the neonates recovered without artificial surfactant therapy. All of the patients recovered without complications, and no infections were confirmed (exclusion criteria). Only 2 of these 10 neonates had a value of polarisation index of the amniotic fluid under the 0.335 cut-off point (respectively 0.318 and 0.320), one was not hospitalised and had tachypnea of the new-born.

Table 3 shows the neonatal respiratory morbidity in relation to the maternal and neonatal characteristics. The duration between the beginning of the caesarean and birth was similar in both groups $(5[3-7] \mathrm{mn})$. In the univariate analysis, body mass index and the rate of AFI (Fluorescence Polarisation Index $>0.335$ ) were significantly higher in women whose infants had respiratory morbidity. These two variables appeared to be independently associated with neonatal respiratory morbidity also in the multivariate analysis (odds ratio, 1.12 [95\% confidence interval, 1.02-1.22], $\mathrm{p}=0.019$ for body mass index, and 6.11 [95\% confidence interval, 1.20-31.11], $\mathrm{p}=0.029$ for AFI). The sensitivity and specificity of the fluorescence polarisation index above 0.335 for detecting neonatal respiratory morbidity were $80 \%$ and $64 \%$, respectively.

Maternal and neonatal characteristics according to AFI groups are presented in table 4. Shorter duration of gestation with caesarean delivery before 39 weeks, lack of labour before the caesarean delivery, female gender, and respiratory morbidity were significantly associated with AFI in the univariate analysis. In the multivariate analysis, gestational age at the time of caesarean delivery was inversely associated with AFI (odds ratio, 0.46 [95\% confidence interval, 0.29-0.71], $\mathrm{p}<0.001)$, female gender was associated with an increased risk of AFI (odds ratio, 3.29 [95\% confidence interval, 1.48-7.31], $\mathrm{p}=0.004$ ), and neonatal respiratory 
morbidity tended to be also associated without reaching significance (table 5). The Fluorescence Polarisation Index reflecting the microviscosity of the lung surfactant phospholipids decreased with the gestational age in the at-term caesarean deliveries (figure 1). We observed that at term, the fluorescence polarisation index appeared higher for girls than for boys. 


\section{Comments:}

To our knowledge, this is the first published study evaluating the fluorescence polarisation of amniotic fluid (reflecting foetal lung maturity) during caesarean delivery at term. In the present study, $7.3 \%$ of infants presented with neonatal respiratory morbidity after caesarean delivery at term. We found that the fluorescence polarisation of amniotic fluid was still decreasing during the last month of pregnancy (between 37 and 41 weeks) (figure 1). AFI was inversely associated with gestational age in particular when caesareans occurred before 39 weeks of gestation. This finding provides a physiological rational that delaying elective caesarean delivery until 39 weeks' gestation is a logical strategy to decrease foetal lung immaturity and (consequently) neonatal respiratory morbidity, as proposed in previous studies and the recommendation of the American College of Obstetricians and Gynecologists (ACOG) $[1,3,5,20,21]$.

It is noteworthy that we observed a high dispersion of polarisation index values (figure 1). This dispersion most likely reflects causes other than the quality of the amniotic fluid surfactant in relation to foetal lung maturity. We found that the microviscosity of phospholipids in amniotic fluid measured by fluorescence polarisation (figure 1 and table 5) is lower for male than female infants at term. This finding suggests a higher maturity of phospholipids in amniotic fluid for male infants with 37-38 weeks. However, most of the published studies for preterm or term neonates show that the male gender is a risk factor for respiratory morbidity and NICU admission [22, 23]. This contradictory finding indicates that further investigations for term neonates are required. Another interesting finding is that neonatal respiratory morbidity was significantly associated with higher body mass index but not with amniotic fluid microviscosity measured by fluorescence polarisation (table 4). Some studies also showed more respiratory morbidity in the neonates born to obese women [24]. These findings may indicate that respiratory morbidity in neonates born to women with high 
body mass index is related to biological events other than the maturity of surfactant production.

Our study has some limitations. First, this was a 1-year pilot proof of concept study performed without a priori power calculation and therefore we found a small rate of respiratory morbidity among neonates. However, even with this small sample size, we showed that AFI was significantly associated with respiratory morbidity. Second, the concept of a cut-off term of 37 weeks gestation abruptly separating two different populations (from a respiratory point of view) may be questioned. Indeed, the maturity of amniotic fluid increases continuously during the last month of pregnancy (figure 1). Thus, foetal lung maturity cannot be only reduced to gestational ages greater than 37 weeks; spontaneous labour, which is associated with lung maturation, must also be considered [8]. The concept of "early term" for neonates between 37 weeks and 38 6/7 weeks must be reinforced to identify their immaturity relative to those neonates at 39 weeks or greater [25].

In conclusion, the present study demonstrated that the maturity of the amniotic fluid was still increasing during the last month of pregnancy (between 37 and 41 weeks). AFI was significantly associated with neonatal respiratory morbidity and independently correlated with shorter gestational age especially before 39 weeks of gestation. This finding provides a physiological rational for recommending delaying elective caesarean delivery until 39 weeks of gestation, as indicated by the ACOG recommendations.

\section{Acknowledgment:}

The authors thank American Journal Experts for editing the manuscript. 


\section{References:}

[1] De Luca R, Boulvain M, Irion O, Berner M, Pfister RE. Incidence of early neonatal mortality and morbidity after late-preterm and term cesarean delivery. Pediatrics 2009;123: e1064-71.

[2] Vendittelli F, Riviere O, Crenn-Hebert C, Claris O, Tessier V, Pinquier D, Teurnier F, Lansac J, Maria B. [Audipog perinatal network. Part 1: principal perinatal health indicators, 2004-2005]. Gynecol Obstet Fertil 2008;36: 1091-100.

[3] Tita AT, Landon MB, Spong CY, Lai Y, Leveno KJ, Varner MW, Moawad AH, Caritis SN, Meis PJ, Wapner RJ, Sorokin Y, Miodovnik M, Carpenter M, Peaceman AM, O'Sullivan MJ, Sibai BM, Langer O, Thorp JM, Ramin SM, Mercer BM. Timing of elective repeat cesarean delivery at term and neonatal outcomes. N Engl J Med 2009;360: 111-20.

[4] Weaver JJ, Statham H, Richards M. Are there "unnecessary" cesarean sections? Perceptions of women and obstetricians about cesarean sections for nonclinical indications. Birth 2007;34: 32-41.

[5] Hansen AK, Wisborg K, Uldbjerg N, Henriksen TB. Risk of respiratory morbidity in term infants delivered by elective caesarean section: cohort study. Bmj 2008;336: 85-7.

[6] Kamath BD, Todd JK, Glazner JE, Lezotte D, Lynch AM. Neonatal outcomes after elective cesarean delivery. Obstet Gynecol 2009;113: 1231-8.

[7] Pfister RE, Ramsden CA, Neil HL, Kyriakides MA, Berger PJ. Volume and secretion rate of lung liquid in the final days of gestation and labour in the fetal sheep. J Physiol 2001;535: 889-99.

[8] Stockx EM, Pfister RE, Kyriakides MA, Brodecky V, Berger PJ. Expulsion of liquid from the fetal lung during labour in sheep. Respir Physiol Neurobiol 2007;157: 403-10.

[9] Jain L, Eaton DC. Alveolar fluid transport: a changing paradigm. Am J Physiol Lung Cell Mol Physiol 2006;290: L646-L648.

[10] Jain L, Chen XJ, Ramosevac S, Brown LA, Eaton DC. Expression of highly selective sodium channels in alveolar type II cells is determined by culture conditions. Am J Physiol Lung Cell Mol Physiol 2001;280: L646-58.

[11] Ramachandrappa A, Jain L. Elective cesarean section: its impact on neonatal respiratory outcome. Clin Perinatol 2008;35: 373-93, vii.

[12] Petersen LC, Birdi KS. The effect of fetal pulmonary surfactant production on the apparent microviscosity of amniotic fluid measured by fluorescence polarization. Scand J Clin Lab Invest 1983;43: 41-7.

[13] Labbe A, Motta C. [Study of the microviscosity of phospholopids in tracheal aspirates by fluorescence polarization. Its application to neonatal respiratory distress]. Pediatrie 1984;39: 25-32.

[14] Motta C. [Various amniotic studies in the assessment of fetal pulmonary maturity]. Ann Biol Clin (Paris) 1982;40: 249-54.

[15] Stark RI, Blumenfeld TA, Cheskin HS, Dyrenfurth I, James LS. Amniotic fluid fluorescence polarization value as a predictor of respiratory distress syndrome. J Pediatr 1980;96: 301-4.

[16] Mamelle N, Munoz F, Grandjean H. [Fetal growth from the AUDIPOG study. I. Establishment of reference curves]. J Gynecol Obstet Biol Reprod (Paris) 1996;25: 61-70.

[17] Report of working group of the British Association of Perinatal Medicine and Neonatal Nurses Association on categories of babies requiring neonatal care. Arch Dis Child 1992;67: 868-9.

[18] Stark AR, Cloherty JP. Manual of neonatal care. 4th ed. ed: Philadelphia-New York: Lippincott-Raven; 1998. 
[19] De Luca AK, Nakazawa CY, Azevedo BC, Rudge MV, De Araujo Costa RA, Calderon IM. Influence of glycemic control on fetal lung maturity in gestations affected by diabetes or mild hyperglycemia. Acta Obstet Gynecol Scand 2009;88: 1036-40.

[20] Morrison JJ, Rennie JM, Milton PJ. Neonatal respiratory morbidity and mode of delivery at term: influence of timing of elective caesarean section. Br J Obstet Gynaecol 1995; 102: 101-6.

[21] Ehrenthal DB, Hoffman MK, Jiang X, Ostrum G. Neonatal outcomes after implementation of guidelines limiting elective delivery before 39 weeks of gestation. Obstet Gynecol 2011;118: 1047-55.

[22] Yee W, Amin H, Wood S. Elective cesarean delivery, neonatal intensive care unit admission, and neonatal respiratory distress. Obstet Gynecol 2008;111: 823-8.

[23] Tremblay Y, Provost PR. 17Beta-HSD type 5 expression and the emergence of differentiated epithelial Type II cells in fetal lung: a novel role for androgen during the surge of surfactant. Mol Cell Endocrinol 2006;248: 118-25.

[24] McGuire W, Dyson L, Renfrew M. Maternal obesity: consequences for children, challenges for clinicians and carers. Semin Fetal Neonatal Med 2010;15: 108-12.

[25] Engle WA, Kominiarek MA. Late preterm infants, early term infants, and timing of elective deliveries. Clin Perinatol 2008;35: 325-41, vi. 
Figure 1: A boxplot of the fluorescence polarisation index by gender according to the completed gestation week at delivery.

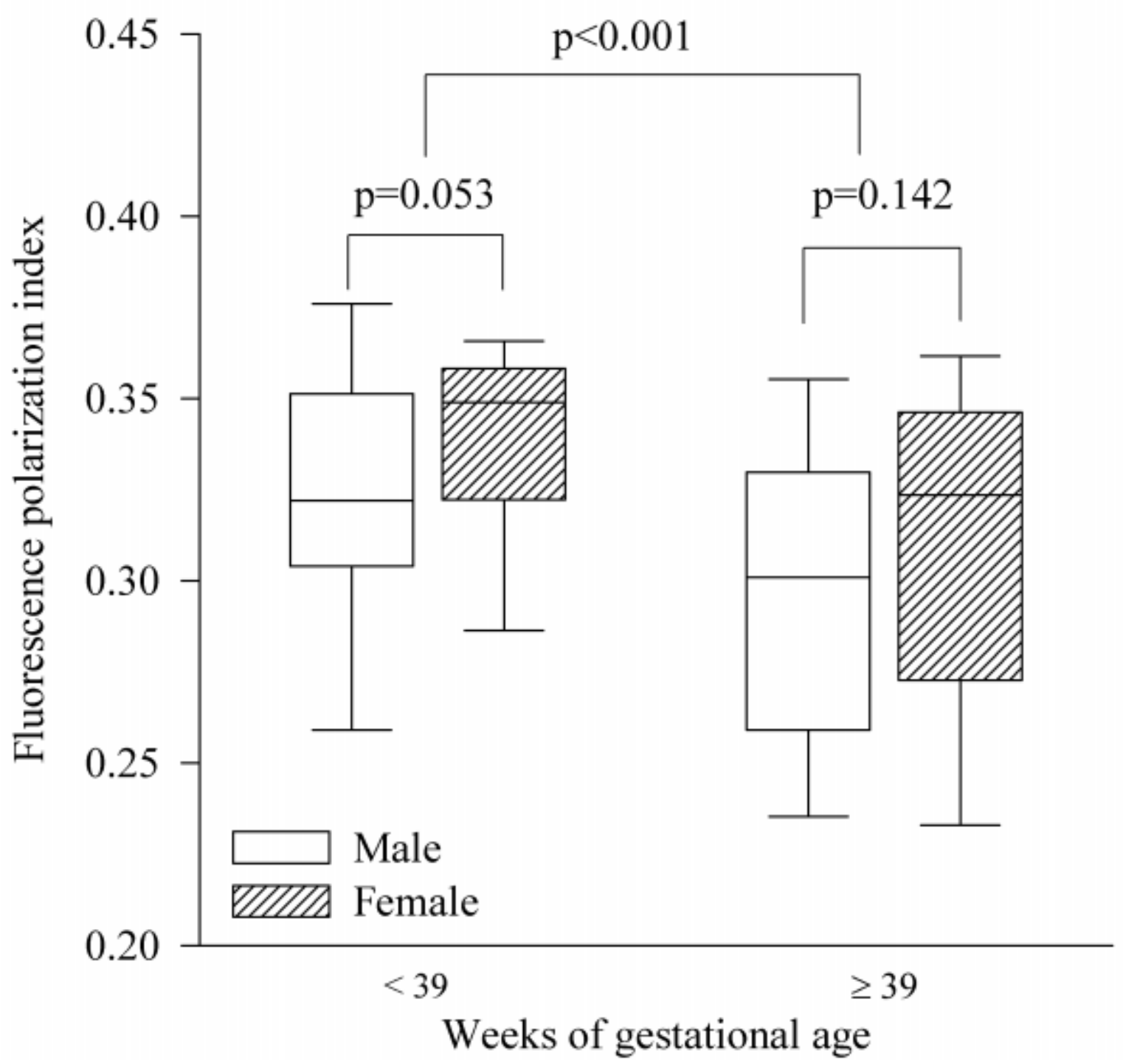


Table 1: Maternal clinical characteristics

\begin{tabular}{lc}
\hline Characteristics & Numbers (\%) \\
\hline Age (years) & $43(32 \%)$ \\
$\bullet \quad 18-29$ & $83(61 \%)$ \\
$\bullet \quad 30-39$ & $10(7 \%)$ \\
- $40-45$ & $27(20 \%)$ \\
Primiparous & $109(80 \%)$ \\
Multiparous & \\
Gestation week at caesarean & \\
delivery & $18(13 \%)$ \\
$\bullet \quad 37$ wk -37 wk $+6 \mathrm{~d}$ & $44(32 \%)$ \\
$\bullet \quad 38$ wk -38 wk $+6 \mathrm{~d}$ & $50(37 \%)$ \\
$\bullet \quad 39$ wk -39 wk $+6 \mathrm{~d}$ & $11(8 \%)$ \\
$\bullet \quad 40$ wk -40 wk $+6 \mathrm{~d}$ & $13(10 \%)$ \\
- More than 41 wk & $12(9 \%)$ \\
Premature rupture of & $115(85 \%)$ \\
membranes & $5(4 \%)$ \\
Elective caesarean section & \\
Emergency caesarean section & $16(12 \%)$ \\
without labour & $3(2 \%)$ \\
Labour before caesarean section & $17(12 \%)$ \\
Preeclampsia & $17(12 \%)$ \\
Diabetes & $96(71 \%)$ \\
Smoking & $1(1 \%)$ \\
Previous caesarean section & \\
Cholestasis of pregnancy & \\
\hline
\end{tabular}

wk: weeks, d: days 
Table 2: Characteristics of neonates with respiratory morbidity and the neonatal treatment

\begin{tabular}{|c|c|c|c|c|c|c|c|c|c|c|}
\hline & $\begin{array}{l}\text { Week } \\
\text { s of } \\
\text { gestat } \\
\text { ion }\end{array}$ & $\begin{array}{l}\text { Gen } \\
\text { der }\end{array}$ & $\begin{array}{l}\text { Weig } \\
\text { ht (g) }\end{array}$ & $\begin{array}{l}\text { Apgar } \\
\text { score } \\
1 / 5 / 10 \mathrm{mn}\end{array}$ & $\begin{array}{l}\text { Hood } \\
\text { cham } \\
\text { ber }\end{array}$ & CPAP & $\begin{array}{l}\text { NICU } \\
\text { admis } \\
\text { sion }\end{array}$ & $\begin{array}{l}\text { Duration } \\
\text { of } \\
\text { hospitalisa } \\
\text { tion in } \\
\text { NICU }\end{array}$ & $\begin{array}{l}\text { Respirat } \\
\text { ory } \\
\text { disease }\end{array}$ & $\begin{array}{l}\text { POLAR } \\
\text { ISATIO } \\
\mathrm{N} \\
\text { INDEX } \\
\text { (cut-off } \\
0.335 \text { ) }\end{array}$ \\
\hline 1 & 39 & $\mathrm{~F}$ & 4,040 & $8 / 9 / 10$ & yes & yes & yes & $2 \mathrm{~d}$ & RDS & 0.337 \\
\hline 2 & $381 / 2$ & $\mathrm{~F}$ & 2,815 & $8 / 10 / 10$ & yes & no & yes & $1 \mathrm{~d}$ & RDS & 0.339 \\
\hline 3 & 39 & $\mathrm{~F}$ & 3,615 & $9 / 10 / 10$ & yes & no & no & & TTN & 0.348 \\
\hline 4 & 38 & $\mathrm{~F}$ & 2,905 & $10 / 10 / 10$ & yes & no & no & & & 0.362 \\
\hline 5 & 39 & M & 2,940 & $10 / 10 / 10$ & no & yes & yes & $2 d$ & TTN & 0.342 \\
\hline 6 & $371 / 2$ & $\mathrm{~F}$ & 3,290 & $8 / 9 / 9$ & no & yes & yes & $7 \mathrm{~d}$ & TTN & 0.320 \\
\hline 7 & $371 / 2$ & M & 3,980 & $9 / 10 / 10$ & yes & no & yes & $8 \mathrm{~d}$ & TTN & 0.389 \\
\hline 8 & 39 & $\mathrm{~F}$ & 3,890 & $9 / 10 / 10$ & no & no & no & & & 0.336 \\
\hline 9 & 39 & M & 3,335 & $8 / 10 / 10$ & no & no & no & & TTN & 0.319 \\
\hline 10 & 37 & $\mathrm{~F}$ & 2,580 & $10 / 10 / 10$ & yes & no & yes & $2 d$ & TTN & 0.354 \\
\hline
\end{tabular}

CPAP: Continuous Positive Airway Pressure, NICU: Neonatal Intensive Care Unit, F: Female, M: male, d: days, RDS: respiratory distress syndrome, TTN: transitory tachypnea of the neonate. Bold: polarisation index $<0.335$ 
Table 3: Neonatal respiratory morbidity related to maternal and neonatal characteristics Aunivariate analysis

\begin{tabular}{cccc}
\hline & $\begin{array}{c}\text { No }(\%) \text { of neonates } \\
\text { with respiratory } \\
\text { morbidity }(n=10)\end{array}$ & $\begin{array}{c}\text { No }(\%) \text { of neonates } \\
\text { without respiratory } \\
\text { morbidity }(n=126)\end{array}$ & $\mathrm{P}$ \\
\hline Maternal age $($ median & $32.5[29.0-38.0]$ & $31.7[29.0-36.0]$ & 0.326 \\
$[Q 1-Q 3])$ & $2(20 \%)$ & $15(12 \%)$ & 0.613 \\
Diabetes & $2(20 \%)$ & $15(12 \%)$ & 0.613 \\
Current smoker & $26.9[21.2-34.9]$ & $22.5[20.3-26.7]$ & $\mathbf{0 . 0 3 9}$ \\
Body mass index & & & 0.077 \\
(median $[Q 1-Q 3])$ & $38.6[37.9-39.0]$ & $39.0[38.4-39.4]$ & 0.343 \\
Weeks of gestation & & & 0.599 \\
(median $[Q 1-Q 3])$ & $6(60 \%)$ & $55(44 \%)$ & 0.606 \\
Weeks of gestation $<39$ & $0(0 \%)$ & $12(10 \%)$ & 0.325 \\
Premature rupture of & & $110(87 \%)$ & 1.000 \\
membranes & $10(100 \%)$ & $61(48 \%)$ & 0.402 \\
No labour before & $7(70 \%)$ & $10(8 \%)$ & $\mathbf{0 , 0 1 4}$ \\
caesarean delivery & $0(0 \%)$ & $23(18 \%)$ & $45(36 \%)$ \\
Female infant & $3(30 \%)$ & $8(80 \%)$ &
\end{tabular}

Bold: $\mathrm{p}<0.05$, Q1: first quartile, Q3: third quartile, FPI: fluorescence polarisation index 
Table 4: Fluorescence polarisation index (FPI) higher or lower than 0.335 related to maternal, neonatal characteristics and neonatal respiratory morbidity - A univariate analysis

\begin{tabular}{|c|c|c|c|}
\hline & $\begin{array}{c}\text { No }(\%) \text { of neonates } \\
\text { with FPI }>0.335 \\
(n=53)\end{array}$ & $\begin{array}{c}\text { No }(\%) \text { of neonates } \\
\text { with FPI } \leq 0.335 \\
(n=83)\end{array}$ & $\mathrm{P}$ \\
\hline \multicolumn{4}{|l|}{ Maternal characteristics } \\
\hline $\begin{array}{l}\text { Maternal Age (median } \\
{[Q 1-Q 3] \text { ) }}\end{array}$ & $32.0[29.0-35.0]$ & $32.0[29.0-36.0]$ & 0.773 \\
\hline Diabetes & $8(15 \%)$ & $9(11 \%)$ & 0.598 \\
\hline Current smoker & $6(11 \%)$ & $10(12 \%)$ & 1.000 \\
\hline $\begin{array}{l}\text { Body Mass Index } \\
\text { (median [Q1-Q3]) }\end{array}$ & $23.8[20.3-27.0]$ & $21.9[20.2-26.6]$ & 0.398 \\
\hline $\begin{array}{l}\text { Weeks of gestation } \\
\text { (median }[Q 1-Q 3] \text { ) }\end{array}$ & $38.7[38.0-39.0]$ & 39.1 [38.7-40.0] & $<0.001$ \\
\hline Weeks of gestation < 39 & $32(60 \%)$ & $28(35 \%)$ & 0.004 \\
\hline $\begin{array}{l}\text { Premature rupture of } \\
\text { membrane }\end{array}$ & $3(6 \%)$ & $9(11 \%)$ & 0.362 \\
\hline $\begin{array}{l}\text { No labour before } \\
\text { caesarean delivery }\end{array}$ & $51(96 \%)$ & $68(84 \%)$ & 0.046 \\
\hline \multicolumn{4}{|l|}{ Neonatal characteristics } \\
\hline Female infant & $37(70 \%)$ & $31(38 \%)$ & $<0.001$ \\
\hline $\begin{array}{l}\text { Restriction of foetal } \\
\text { growth }\end{array}$ & $5(9 \%)$ & $5(6 \%)$ & 0.404 \\
\hline Macrosomia & $11(21 \%)$ & $15(19 \%)$ & 0.824 \\
\hline $\begin{array}{l}\text { Neonatal respiratory } \\
\text { morbidity }\end{array}$ & $8(15 \%)$ & $2(2 \%)$ & 0.014 \\
\hline
\end{tabular}

Bold: $\mathrm{p}<0.05$, Q1: first quartile, Q3: third quartile, FPI: fluorescence polarisation index 
Table 5: Fluorescence polarisation index greater than 0.335 related to maternal and neonatal characteristics - A multivariate analysis

\begin{tabular}{llll}
\hline & \multicolumn{3}{l}{ Fluorescence polarisation index $>$ than 0.335} \\
\cline { 2 - 4 } Female infant & OR & $95 \%$ CI & $P$ \\
\cline { 2 - 4 } Weeks of gestation & 3.29 & $1.48-7.31$ & $\mathbf{0 . 0 0 4}$ \\
& 0.46 & $0.29-0.71$ & $<\mathbf{0 . 0 0 1}$ \\
Neonatal respiratory morbidity & 4.48 & $0.83-24.24$ & 0.081 \\
\hline
\end{tabular}

OR: odds ratio, CI: confidence interval, bold: $\mathrm{p}<0.05$ 